\title{
Effect of planting dates and varieties on growth, fruit yield and quality of bell pepper (Capsicum annuum L.)
}

\author{
Sagar Koner, Ranjit Chatterjee* and Suchand Datta ${ }^{1}$ \\ Department of Vegetable and Spice Crops, Uttar Banga Krishi Viswavidyalaya, Pundibari, Cooch Behar-736165 \\ (West Bengal), INDIA \\ ${ }^{1}$ Regional Research Station, Terai Zone, Uttar Banga Krishi Viswavidyalaya, Pundibari, Cooch Behar-736165 \\ (West Bengal), INDIA \\ *Corresponding author. E-mail: ranchat22@rediffmail.com
}

Received: February 23, 2015; Revised received: July 27, 2015; Accepted:September 16, 2015

\begin{abstract}
Bell pepper (Capsicum annuum L.) is highly sensitive to temperature variation and high temperature promotes flower drops and reduce fruit yield. An experiment was undertaken to identify suitable planting time of bell pepper and stable performed varieties for different plating dates during the winter season of 2011-12 and 2012-13 at U.B.K.V., Pundibari, West Bengal, India. The experiment was laid out in split plot design with 3 replications. Three planting dates $\left(15^{\text {th }}\right.$ November, $30^{\text {th }}$ November and $15^{\text {th }}$ December) were allotted in sub plots while 4 varieties (Mekong, California Wonder, JK Peeyali and Asha) were placed in main plots. Bell pepper responded differently with the changes in planting dates irrespective of years. The $30^{\text {th }}$ November planting date emerged best in terms of different and growth and yield attributes. Among the varieties, Mekong emerged as superior in terms of more number of fruits (10.24), fruit weight $(65.50 \mathrm{~g})$ and yield $(670.76 \mathrm{~g} / \mathrm{plant}$ and $18.11 \mathrm{t} / \mathrm{ha})$ while maximum beta carotene and vitamin $C$ were recorded in the variety California Wonder $(0.071 \mu \mathrm{g} / 100 \mathrm{~g}$ fresh fruits, $154.80 \mathrm{mg} / 100 \mathrm{~g}$ fresh fruits, respectively). The interaction effect showed that variety Mekong transplanted on $15^{\text {th }}$ December resulted in many fold improvement in the form of highest leaf area $\left(8.79 \mathrm{~cm}^{2}\right)$, maximum number of fruits/ plant, fruit weight $(86.93 \mathrm{~g})$ and fruit yield $(854.69 \mathrm{~g} / \mathrm{plant}$ and $23.08 \mathrm{t} / \mathrm{ha})$. The result established that $30^{\text {th }}$ November is ideal for bell pepper planting and the variety Mekong is the most stable performing variety with respect to the different planting dates.
\end{abstract}

Keywords: Bell pepper, Planting date, Quality, Variety, Yield

\section{INTRODUCTION}

Bell pepper or sweet pepper or Capsicum is a high value luxury vegetable belongs to family Solanaceae. Bell pepper occupies a pride of place among vegetables in Indian cuisine because of its delicacy and pleasant flavour. The fruit is a potential antioxidants and rich in vitamin A and vitamin C. The crop is highly sensitive to environmental stresses particularly temperature. High temperature promoted flower drop and reduced fruit set in bell pepper (Erickson and Markhart, 2001). High day temperature $\left(20-24^{0} \mathrm{C}\right)$ along with low light intensity (30\% shade) or higher night temperature $\left(24^{0} \mathrm{C}\right)$ prompted flower drop in bell pepper (Rylski and Halevy, 1974). During high temperature certain physiological changes occur within the plant system like decrease in sugar content and lower enzymatic activities which encourage abnormal pollen and anther development, resulting in decrease in pollen viability, pollen tube growth and abortion of buds, flowers and young fruits (Turner and Wien, 1994). The optimal planting date is a date in which all environmental factors (water, light, soil, etc.) will be used by the crop in order to produce the maximum yield (Ghovatia et al., 1993). The planting date should therefore be identified in such a way that the crop has the required time for germination, growth, flowering and seeding and appropriate synchronization of flowering with temperatures so that it can use the maximum light and favorable temperatures and produce a high quality yield (Nahardani et al., 2013). The prolong winter and high soil moisture of terai region encourages cultivation of bell pepper during winter months. However, delayed planting and wrong selection of varieties resulted in inconsistent yield and poor return from bell pepper cultivation. This clearly indicates the necessity to identify the suitable varieties and optimum planting time of bell pepper. However information regarding the optimum time of planting as well as the interaction effect in combination with varieties on performance of bell pepper is scanty under moist humid climate of eastern Himalayan region. Keeping in view the tremendous potential of bell pepper, the present study was formulated to evaluate the most suitable bell pepper varieties for different planting dates and to select most stable performed variety under 
Table 1. Effect of planting dates and varieties on growth, yield and quality of bell pepper (Pooled mean of two years).

\begin{tabular}{|c|c|c|c|c|c|c|c|c|c|}
\hline Treatment & $\begin{array}{c}\text { Plant } \\
\text { height } \\
(\mathrm{cm})\end{array}$ & $\begin{array}{r}\text { Num- } \\
\text { ber of } \\
\text { leaves/ } \\
\text { plant }\end{array}$ & $\begin{array}{l}\text { Leaf } \\
\text { area } \\
\left(\mathrm{cm}^{2}\right)\end{array}$ & $\begin{array}{c}\text { Leaf } \\
\text { chlorophyll } \\
\text { (SPAD } \\
\text { value) }\end{array}$ & $\begin{array}{c}\text { Days to } \\
50 \% \\
\text { flower- } \\
\text { ing }\end{array}$ & $\begin{array}{c}\text { Days to } \\
\text { first har- } \\
\text { vesting }\end{array}$ & $\begin{array}{c}\text { Fruit } \\
\text { weight } \\
\text { (g) }\end{array}$ & $\begin{array}{c}\text { Beta- } \\
\text { carotene } \\
\text { ( } \mu \mathrm{g} / 100 \mathrm{~g} \\
\text { fresh } \\
\text { fruit) }\end{array}$ & $\begin{array}{c}\text { Vitamin C } \\
(\mathrm{mg} / 100 \mathrm{~g} \\
\text { fresh fruit) }\end{array}$ \\
\hline \multicolumn{10}{|c|}{ Planting date level } \\
\hline $\mathrm{P}_{1}$ & 44.60 & 127.32 & 5.78 & 54.23 & 98.24 & 130.21 & 64.47 & 0.066 & 143.21 \\
\hline $\mathrm{P}_{2}$ & 37.02 & 160.40 & 5.80 & 55.39 & 96.53 & 123.71 & 64.94 & 0.067 & 141.88 \\
\hline $\mathrm{P}_{3}$ & 29.88 & 180.84 & 5.61 & 52.61 & 88.98 & 115.32 & 56.05 & 0.062 & 136.18 \\
\hline $\mathrm{CD}(\mathrm{P}=0.05)$ & 2.54 & 2.53 & 0.22 & 1.27 & 1.84 & 1.13 & 1.78 & 0.014 & 1.24 \\
\hline \multicolumn{10}{|l|}{ Variety level } \\
\hline $\mathrm{V}_{1}$ & 31.27 & 181.06 & 4.90 & 51.69 & 101.65 & 130.78 & 65.50 & 0.068 & 147.22 \\
\hline $\mathrm{V}_{2}$ & 38.35 & 206.48 & 4.45 & 47.71 & 108.94 & 134.67 & 43.16 & 0.071 & 154.80 \\
\hline $\mathrm{V}_{3}$ & 34.64 & 105.83 & 5.01 & 56.87 & 84.42 & 108.13 & 63.13 & 0.056 & 119.30 \\
\hline $\mathrm{V}_{4}$ & 44.41 & 131.38 & 8.54 & 60.03 & 83.34 & 118.73 & 75.48 & 0.065 & 140.37 \\
\hline $\mathrm{CD}(\mathrm{P}=0.05)$ & 2.52 & 2.64 & 0.23 & 1.94 & 1.63 & 2.13 & 1.79 & 0.015 & 1.99 \\
\hline \multicolumn{10}{|l|}{ Interaction } \\
\hline $\mathrm{P}_{1} \mathrm{~V}_{1}$ & 36.44 & 146.68 & 4.48 & 46.32 & 107.82 & 138.70 & 55.59 & 0.061 & 140.48 \\
\hline $\mathrm{P}_{1} \mathrm{~V}_{2}$ & 36.44 & 146.68 & 4.48 & 46.32 & 107.82 & 138.70 & 55.59 & 0.061 & 140.48 \\
\hline $\mathrm{P}_{1} \mathrm{~V}_{3}$ & 47.83 & 171.61 & 4.77 & 52.69 & 115.33 & 139.68 & 52.32 & 0.080 & 165.24 \\
\hline $\mathrm{P}_{1} \mathrm{~V}_{4}$ & 41.30 & 86.33 & 5.31 & 61.90 & 87.18 & 116.73 & 76.70 & 0.062 & 128.05 \\
\hline $\mathrm{P}_{2} \mathrm{~V}_{1}$ & 52.84 & 104.66 & 8.55 & 56.00 & 82.65 & 125.72 & 73.27 & 0.063 & 139.48 \\
\hline $\mathrm{P}_{2} \mathrm{~V}_{2}$ & 29.58 & 185.19 & 4.90 & 52.71 & 101.70 & 131.16 & 68.05 & 0.071 & 149.26 \\
\hline $\mathrm{P}_{2} \mathrm{~V}_{3}$ & 37.35 & 212.71 & 4.53 & 48.28 & 103.81 & 135.07 & 44.48 & 0.071 & 152.04 \\
\hline $\mathrm{P}_{2} \mathrm{~V}_{4}$ & 36.45 & 105.88 & 4.97 & 56.67 & 89.72 & 107.89 & 60.31 & 0.057 & 121.90 \\
\hline $\mathrm{P}_{3} \mathrm{~V}_{1}$ & 44.72 & 137.81 & 8.79 & 63.90 & 90.90 & 120.71 & 86.93 & 0.070 & 144.32 \\
\hline $\mathrm{P}_{3} \mathrm{~V}_{2}$ & 27.80 & 211.30 & 5.32 & 56.04 & 95.43 & 122.47 & 72.87 & 0.073 & 152.32 \\
\hline $\mathrm{P}_{3} \mathrm{~V}_{3}$ & 29.87 & 235.12 & 4.06 & 42.18 & 107.69 & 129.28 & 32.69 & 0.062 & 147.14 \\
\hline $\mathrm{P}_{3} \mathrm{~V}_{4}$ & 26.19 & 125.30 & 4.76 & 52.04 & 76.35 & 99.78 & 52.39 & 0.050 & 107.94 \\
\hline $\mathrm{CD}(\mathrm{P}=0.05)$ & 4.37 & 4.57 & 0.40 & 3.35 & 2.83 & 3.69 & 3.10 & 0.025 & 3.44 \\
\hline
\end{tabular}

Treatment details: $\mathrm{P}_{1}-15^{\text {th }}$ November; $\mathrm{P}_{2}-30^{\text {th }}$ November; $\mathrm{P}_{3}-15^{\text {th }}$ December; $\mathrm{V}_{1^{-}}$Mekong; $\mathrm{V}_{2^{-}}$California Wonder; $\mathrm{V}_{3^{-}}$JK Peeyali; $\mathrm{V}_{4}$ - Asha. CD: Critical difference.

different planting dates.

\section{MATERIALS AND METHODS}

The study was carried out at the Instructional Farm of UBKV, Pundibari, Coochbehar, West Bengal, India during winter season (November to February) of 201112 and 2012-2013. The site is located at $89^{\circ} 23^{\prime} 53^{\prime \prime} \mathrm{E}$ longitude and $26^{\circ} 19^{\prime} 86^{\prime \prime} \mathrm{N}$ latitude and at $43 \mathrm{~m}$ above mean sea level. The soil was sandy loam $(63 \%, 22 \%$ and $19 \%$ sand, silt and clay respectively) in texture and slight acidic in reaction $(\mathrm{pH} 5.78)$. The initial soil organic carbon was $0.82 \%$ and available $\mathrm{N}, \mathrm{P}$ and $\mathrm{K}$ contents were $172.12,20.11$ and $122.80 \mathrm{~kg} / \mathrm{ha}$ respectively. Three planting dates $\left[15^{\text {th }}\right.$ November $\left(\mathrm{P}_{1}\right), 30^{\text {th }}$ November $\left(\mathrm{P}_{2}\right)$ and $15^{\text {th }}$ December $\left.\left(\mathrm{P}_{3}\right)\right]$ were allotted in sub plots while 4 varieties [Mekong $\left(\mathrm{V}_{1}\right)$, California Wonder $\left(\mathrm{V}_{2}\right)$, JK Peeyali $\left(\mathrm{V}_{3}\right)$ and Asha $\left(\mathrm{V}_{4}\right)$ ] were placed in main plots. Thus, 12 treatment combinations were laid out in split plot design with three replications. The varieties Mekong, JK Peeyali and Asha were hybrids whereas California Wonder was an open pollinated variety. Bell pepper seedlings were transplanted on $15^{\text {th }}$ November, $30^{\text {th }}$ November and $15^{\text {th }}$ December for both the years in $3 \mathrm{~m} \times 3 \mathrm{~m}$ plots with both ways spacing of $60 \mathrm{~cm}$. Recommended farmyard manure $(15 \mathrm{t} / \mathrm{ha})$ was applied three weeks before transplanting and for the recommended inorganic fertilizers (120: 60: $60 \mathrm{~kg} \mathrm{NPK/ha),} \mathrm{full} \mathrm{dose}$ of phosphorus and potash along with half nitrogen were applied as basal and rest nitrogen was top dressed in two equal splits at 30 and 60 days after transplanting. The crop was raised adopting standard cultural

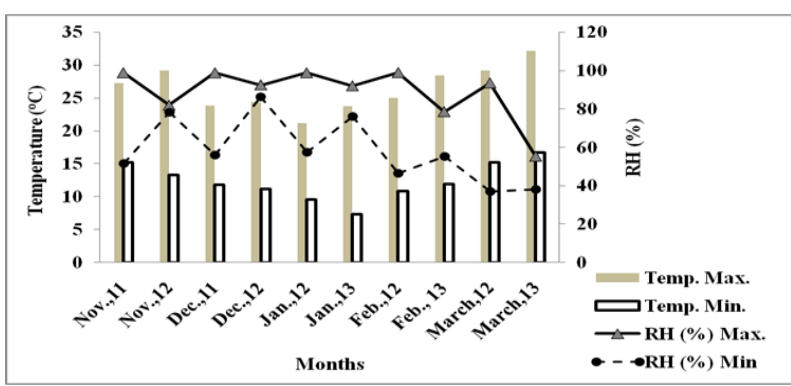

Fig. 1. Meteorological parameters during the period of field experiment. 
Table 2. Effect of planting dates and varieties on number of fruits and fruit yield of bell pepper.

\begin{tabular}{|c|c|c|c|c|c|c|c|c|c|}
\hline \multirow[t]{2}{*}{ Treatment } & \multicolumn{3}{|c|}{ Number of fruits/plant } & \multicolumn{3}{|c|}{ Yield/plant (g) } & \multicolumn{3}{|c|}{ Yield (t/ha) } \\
\hline & $2011-12$ & $2012-13$ & Pooled & $2011-12$ & $2012-13$ & Pooled & $2011-12$ & $2012-13$ & Pooled \\
\hline \multicolumn{10}{|c|}{ Planting date level } \\
\hline $\mathrm{P}_{1}$ & 8.15 & 8.72 & 8.44 & 540.38 & 534.58 & 537.48 & 14.59 & 14.43 & 14.51 \\
\hline $\mathrm{P}_{2}$ & 8.47 & 8.71 & 8.59 & 569.10 & 558.77 & 563.94 & 15.37 & 15.09 & 15.23 \\
\hline $\mathrm{P}_{3}$ & 7.81 & 8.06 & 7.93 & 459.07 & 465.03 & 462.05 & 12.39 & 12.55 & 12.48 \\
\hline $\mathrm{CD}(\mathrm{P}=0.05)$ & 0.61 & 0.83 & 0.43 & 52.51 & 27.74 & 24.66 & 1.42 & 0.74 & 0.67 \\
\hline \multicolumn{10}{|l|}{ Variety level } \\
\hline $\mathrm{V}_{1}$ & 9.62 & 10.85 & 10.24 & 647.48 & 694.03 & 670.76 & 17.48 & 18.74 & 18.11 \\
\hline $\mathrm{V}_{2}$ & 7.20 & 6.54 & 6.87 & 298.05 & 261.20 & 279.62 & 8.05 & 7.05 & 7.55 \\
\hline $\mathrm{V}_{3}$ & 7.88 & 8.04 & 7.96 & 529.87 & 497.61 & 513.74 & 14.31 & 13.43 & 13.87 \\
\hline $\mathrm{V}_{4}$ & 7.88 & 8.54 & 8.21 & 616.00 & 625.00 & 620.50 & 16.63 & 16.87 & 16.76 \\
\hline $\mathrm{CD}(\mathrm{P}=0.05)$ & 0.82 & 0.83 & 0.56 & 27.06 & 30.47 & 19.67 & 0.73 & 0.82 & 0.53 \\
\hline \multicolumn{10}{|l|}{ Interaction } \\
\hline $\mathrm{P}_{1} \mathrm{~V}_{1}$ & 7.91 & 9.42 & 8.67 & 445.60 & 496.21 & 470.91 & 12.03 & 13.40 & 12.72 \\
\hline $\mathrm{P}_{1} \mathrm{~V}_{2}$ & 9.46 & 8.24 & 8.85 & 450.95 & 391.32 & 421.14 & 12.18 & 10.56 & 11.37 \\
\hline $\mathrm{P}_{1} \mathrm{~V}_{3}$ & 8.41 & 9.91 & 9.16 & 783.08 & 739.40 & 761.24 & 21.14 & 19.96 & 20.55 \\
\hline $\mathrm{P}_{1} \mathrm{~V}_{4}$ & 6.83 & 7.31 & 7.07 & 481.90 & 511.39 & 496.65 & 13.01 & 13.81 & 13.41 \\
\hline $\mathrm{P}_{2} \mathrm{~V}_{1}$ & 9.80 & 10.78 & 10.29 & 665.94 & 707.42 & 686.68 & 17.98 & 19.10 & 18.54 \\
\hline $\mathrm{P}_{2} \mathrm{~V}_{2}$ & 7.31 & 6.81 & 7.06 & 298.00 & 269.11 & 283.56 & 8.04 & 7.26 & 7.65 \\
\hline $\mathrm{P}_{2} \mathrm{~V}_{3}$ & 7.94 & 7.39 & 7.67 & 452.92 & 432.24 & 442.58 & 12.23 & 11.67 & 11.95 \\
\hline $\mathrm{P}_{2} \mathrm{~V}_{4}$ & 8.84 & 9.85 & 9.35 & 859.55 & 826.31 & 842.93 & 23.21 & 22.31 & 22.76 \\
\hline $\mathrm{P}_{3} \mathrm{~V}_{1}$ & 11.15 & 12.36 & 11.76 & 830.90 & 878.47 & 854.69 & 22.43 & 23.72 & 23.08 \\
\hline $\mathrm{P}_{3} \mathrm{~V}_{2}$ & 4.84 & 4.57 & 4.71 & 145.19 & 123.17 & 134.18 & 3.92 & 3.32 & 3.62 \\
\hline $\mathrm{P}_{3} \mathrm{~V}_{3}$ & 7.29 & 6.83 & 7.06 & 353.62 & 321.19 & 337.41 & 9.55 & 8.67 & 9.11 \\
\hline $\mathrm{P}_{3} \mathrm{~V}_{4}$ & 7.96 & 8.47 & 8.22 & 506.55 & 537.31 & 521.93 & 13.68 & 14.51 & 14.10 \\
\hline $\mathrm{CD}(\mathrm{P}=0.05)$ & 1.42 & 1.44 & 0.98 & 46.87 & 52.77 & 34.07 & 1.27 & 0.82 & 0.92 \\
\hline
\end{tabular}

Treatment details: $\mathrm{P}_{1}-15^{\text {th }}$ November; $\mathrm{P}_{2}-30^{\text {th }}$ November; $\mathrm{P}_{3}-15^{\text {th }}$ December; $\mathrm{V}_{1}$-Mekong; $\mathrm{V}_{2^{-}}$California Wonder; $\mathrm{V}_{3^{-}}$JK Peeyali; $V_{4}$ - Asha. CD: Critical difference.

practices. The observation were recorded for plant height, number of leaves per plant, leaf area, leaf chlorophyll, days to $50 \%$ flowering, days to first harvesting, number of fruits/plant, fruit weight, fruit yield, beta carotene content and vitamin $\mathrm{C}$ content of the fruits. The chlorophyll content of the leaf was measured at the time of flowering by portable chlorophyll meter (SPAD 502; Minolta, Japan). The beta carotene content of fruits $(\mu \mathrm{g} / 100 \mathrm{~g})$ was estimated by the procedure given by Srivastava and Kumar (2010). The vitamin C content was determined titrimetrically, using 2, 6 dichlorophenol indophenol dye as per method suggested by Ranganna (1986). Two years data collected on various parameters were pooled and statistically analyzed as per method suggested by Panse and Sukhatme (2000).

\section{RESULTS AND DISCUSSION}

Effect of planting dates: A perusal of data presented in tables 1 and 2 depicted that different planting dates showed significant (at 5\% level of significance) effect on performance of bell pepper and early planting $\left(15^{\text {th }}\right.$ November) resulted in maximum plant height (44.60 $\mathrm{cm})$ and vitamin $\mathrm{C}$ content (143.21 $\mathrm{mg} / 100 \mathrm{~g}$ ) compared to later planting dates of $30^{\text {th }}$ November and $15^{\text {th }}$ December. The yield attributing characters were significantly varied with the variation in planting time.
Bell pepper planted at $30^{\text {th }}$ November emerged as best in terms of more number of fruits (8.69/plant) and maximum yield/plant (563.94 g) and total yield (15.23 $\mathrm{t} / \mathrm{ha})$ compared to later date $\left(15^{\text {th }}\right.$ December $)$ with minimum number of fruits (7.93/plant) and fruit yield (462.05 g/plant and $12.48 \mathrm{t} / \mathrm{ha})$. The results revealed that $30^{\text {th }}$ November planting showed the highest positive impact on the fruit yield/plant and increased by $5 \%$ compared third planting date $\left(15^{\text {th }}\right.$ December $)$ and $18 \%$ compared to the first planting date $\left(15^{\text {th }}\right.$ November). The increase in yield components with $30^{\text {th }}$ November planting date may be attributed to availability of favourable environmental condition (Fig. 1) for appropriate synchronization of flowering and subsequent transformation to fruits for producing optimum yield (Nahardani et al., 2013). However, the results are in contrast of the finding of Alam et al. (2011) who recorded highest fruit yield of sweet pepper (19.36 t/ha) under early planting date $\left(1^{\text {st }}\right.$ October). Oxley and Rivard (2014) also registered highest yield under early planting of bell peppers varieties. Reduction in fruit set in delayed planting may be associated with decreased concentrations of reducing sugars in flower buds and flowers that may results failure of pollination and induce abscission of flowers under high temperature condition (Wien et al., 1989; Erickson and Markhart, 2001). Taskovics et al. 
(2010) also pointed that under high temperature condition fruit set becomes poor and less developed fewer fruits are produced.

Effect of varieties: The pooled results (Tables 1 and 2) revealed that among the varieties, Asha recorded the maximum plant height $(44.41 \mathrm{~cm})$, leaf area $(8.54$ $\mathrm{cm}^{2}$ ), leaf chlorophyll (60.03 SPAD value) as well as fruit weight (75.48 gm). However, the variety Mekong recorded the maximum number of fruits (10.24/plant) and fruit yield $(670.76 \mathrm{~g} / \mathrm{plant}$ and $18.11 \mathrm{t} / \mathrm{ha})$. Among the varieties, California Wonder recorded the minimum number of fruits (6.87) and lowest fruit yield (279.62 g/plant and 7.55 t/ha). Singh et al. (2011) also reported lowest yield of California Wonder among bell pepper varieties. The differential response by different varieties may be due to differences in genetic constituents of the varieties and variable environmental condition (Bergefurd et al., 2011). Saha et al. (2010) observed that high temperature reduced the fruit set percentage as well as fruit size of bell pepper varieties and found that heat tolerance line produced higher amount of proline in expressing the heat tolerant capability. Significant differences for quality attributes between the varieties were observed and the variety California Wonder had recorded the highest beta carotene and vitamin $\mathrm{C}$ content of the fruits $(0.071$ $\mu \mathrm{g} / 100 \mathrm{~g}$ fresh fruits, $154.80 \mathrm{mg} / 100 \mathrm{~g}$ fresh fruits, respectively). However, climatic conditions influenced strongly on the quantity of ascorbic acid and high temperature under late planting (Fig.1) decreased the vitamin $\mathrm{C}$ content of the fruits. Pevicharova et al. (2007) also recorded lower amount of vitamin C content under higher temperature and stated that in bell pepper fruits high day temperature decreased the total vitamin $\mathrm{C}$ of fruits.

Effect of interaction of planting dates and varieties: The result indicated a significant interaction between planting dates and varieties for the growth, fruit yield and quality attributes of bell pepper (Tables 1 and 2). The pooled data showed that the variety Mekong in combination with $15^{\text {th }}$ December planting had recorded the maximum leaf area $\left(8.79 \mathrm{~cm}^{2}\right)$, highest leaf chlorophyll content (63.90 SPAD value) and highest fruit weight $(86.93 \mathrm{~g})$ along with maximum number of fruits (11.76/plant) and fruit yield $(854.69 \mathrm{~g} /$ plant and $23.08 \mathrm{t} / \mathrm{ha}$ ). It seems that moderate temperature in late planting date had a more positive impact on fruit weight and number of fruits per plant for the variety Mekong which enhanced the total fruit yield of the plant (Fig 1). Thanopoulos et al. (2013) observed that the growth and size of bell pepper fruits are highly influenced by air temperature, daylight and relative humidity particularly during anthesis, fruit set, fruit development and maturation stages. The variety Mekong under favourable planting date had emerged as highly efficient in production and translocation of assimilates to the developing sink and accelerated the formation of more fruits and subsequently produced higher fruit yield.

\section{Conclusion}

The findings concluded that $30^{\text {th }}$ November was the most suitable time for bell pepper planting and among the varieties Mekong was the most stable performing variety with respect to the different planting dates. However, Californian Wonder was best for early planting $\left(15^{\text {th }}\right.$ November). Performance of hybrid varieties was better over open pollinated varieties for different planting dates.

\section{REFERENCES}

Alam, M.S., Saha, S.R., Salam, M.A., Alam, M.S. and Alam, M.K. (2011). Effect of sowing time and plant spacing on the yield and yield attributes of sweet pepper, Bangladesh Journal of Agricultural Research, 36(1): 271-278.

Bergefurd, B.R., Lewis, W., Harker, T., Miller, L., Welch, A., Weaks, E. (2011) Bell Pepper Cultivar Performance Trial Grown in Southern Ohio. http:// southcenters.osu.edu/sites/southc/files/site-library/sitedocuments/HORT/ Results/2011/ bellpeppertrial2011.pdf.

Erickson, A.N. and Markhart, A.H. (2001). Flower production, fruit set and physiology of bell pepper during elevated temperature and vapor pressure deficit. Journal of American Society for Horticultural Science, 126(6): 697-702.

Ghovatia, P.K., Ahlawat, R.P., and Trividi, S.J. (1993). Growth and yield of summer green gram as affected by different dates of sowing, Rhizobium inoculation and levels of phosphours. Indian journal of Agronomy, 3 (8):492-994.

Nahardani, A.A., Sinaki, J.M. Firouzabadi, M.B. and Abbaspour H. (2013). Effects of sowing date and biological fertilizer foliar on yield and yield components of cowpea, International Journal of Agronomy and Plant Production, 4 (11): 2822-2826.

Oxley, K. L., Cary, L.R. (2014) Evaluation of Hybrid Bell Pepper Varieties for High Tunnel Production in Kansas. https://www.hightunnels.org

Panse, V.G. and Sukhatme, P.V. (2000). Statistical methods for agricultural workers. ICAR Publications, New Delhi,India.

Pevicharova, G., Todorova, V. and Todorov, J. (2007). Ascorbic acid and total sugars content of Kapya type pepper depending on cultivars and climatic conditions. Rasteniev-dni-Nauki, 44(1): 52-56.

Ranganna, S. (1986). Analysis and quality control for fruit and vegetable products. $2^{\text {nd }}$ edition, Tata.Mc Graw-Hill publishing company Ltd. New Delhi, India.

Rylski, I. and Halevy, A.H. (1974). Optimal environment for set and development of sweet pepper fruit. Acta Horticulture, 42:55-62.

Saha, S.R., Hossain, M.M., Rahman, M.M., Kuo, C.G. and Abdullah, S. (2010). Effect of high temperature stress on the performance of twelve sweet pepper genotypes. Bangladesh Journal Agricultural Research, 35(3): 525-534.

Singh, A.K., Singh, B. and Gupta, R. (2011) Performance of sweet pepper ( Capsicum annum) varieties and economics under protected and open field conditions in 
Uttarakhand. Indian Journal of Agricultural Sciences, 81(10): 973-975.

Srivastava, R.P., Kumar, S. (2010). Fruit and Vegetable Preservation Principles and practices. International Book Distributing Company. Lucknow, India.

Taskovics, Z.T., Orosz, F. and Kovacs, A. (2010). The effect of some environment factors on the growth of sweet pepper. Acta Universitatis Sapientiae Agriculture and Environment, 2: 17-22.

Thanopoulos, C., Akoumianakis, K. and Passam, H. (2013). The effect of season on the growth and maturation of bell peppers. International Journal of Plant Production, 7(2): 279-294.

Turner, A.D. and Wien, H.C. (1994). Photosynthesis, dark respiration and bud sugar concentrations in pepper cultivars differing in susceptibility to stress-induced bud abscission. Annals of Botany, 73: 623-628.

Wien, H.C., Tripp, K.E., Hernandez-Armenta, R. and Turner, A.D. (1989). Abscission of reproductive structures in pepper: causes, mechanisms and control. In: Green SK, ed. Tomato and pepper production in the tropics. Taipei, Taiwan, R.O.C: Asian Vegetable Research and Development Center, 150-165. 